\title{
AL
}

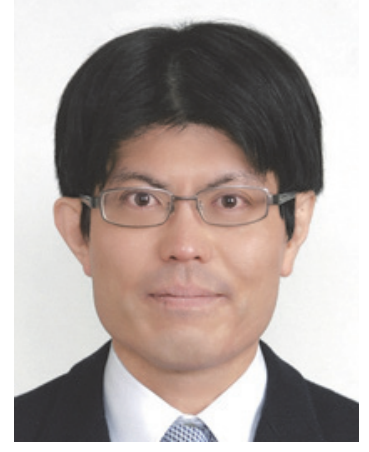

\section{濱路 政嗣}

京都大学 医学研究科 呼吸器外科学

2001 年 京都大学医学部卒業

2001 年 京都大学医学部附属病院 心臓血管外科研修医

2002 年 静岡市立静岡病院 心臟血管外科専攻医

2005 年 市立長浜病院 心藏血管外科

2007 年 国立病院機構長良医療センター 呼吸器外科

2009 年 米国メイヨークリニック一般胸部外科

2011 年 米国ブリガムアンドウイメンズ病院胸部外科

2012 年 京都大学医学研究科博士課程

2016 年 京都大学医学研究科呼吸器外科学 助教

2019 年 京都大学医学研究科呼吸器外科学 講師 


\section{外向型アメリカ嗅床研修と内向型人間の私}

現在に至る私の呼吸器外科臨床と研究の過半は、3 年間のアメリカ臨床研修に由来している。肺移植トレー ニングを除くと、呼吸器外科分野でアメリカ臨床研修を経験した者は非常に少ないため、そのアメリカ臨床研 修を中心に括話しする。アメリカは日本とは異なる、「自己主張が必要な」つまり「外向的な」国と考えられ ているが、アメリカ臨床研修にも同様であり、「外向型人間」が向いているのだろうか? スーザンケイン著「内 向型人間の時代」によれば、アメリカと言えども、約 3 分の 1 から半数の人間が「内向型人間」であるといい、 歴史的にも内向型人間は意外に多かった。アメリカ臨床研修においても、「外向型要素」は強いが、「内向型人 間」が生き残れないわけではなく、周囲と上司の理解次第である。演者は、アメリカ臨床研修から現時点に至 るまで、幸運にも上司に恵まれ続けた結果、本学会賞の受賞に至った。 